\title{
Satellite based seasonal land use classification and change detection analysis of landsat-8 operational land imager
}

\author{
Wasim Pervez 1,", Shoab Ahmad Khan ${ }^{1}$, Ejaz Hussain ${ }^{1}$, and Faisal Amir ${ }^{1}$ \\ ${ }^{1}$ National University of Sciences and Technology H-12, 44000, Islamabad, Pakistan
}

\begin{abstract}
This study investigated the Landsat-8 Operational Land Imager (OLI) to determine its suitability for change detection analysis and mapping applications due to its enhanced signal-to-noise ratio (SNR), spectral band configuration, technical superiority, improved system design and high radiometric resolution. Earlier Landsat series had a lower SNR, comparatively smaller radiometric resolution and limitations in spectral band configurations. Pre-classification methods e.g., image differencing; image rationing, vegetation indices and principal components used for change detection analysis do not indicate type of the change due to its limitations. Therefore, better technique of post classification change detection was used on OLI data in the study area which provided information of the type of the change i.e., from-to change detection. This paper evaluated the OLI support vector machines (SVM) classification suitability using data covering four different seasons (i.e., spring, autumn, winter, and summer) after pre-processing and atmospheric correction. After classification, the major change detection results of OLI SVM-classified data for the four seasons were compared to change detection results of six cases: (1) winter to spring; (2) winter to summer; (3) winter to autumn; (4) spring to summer; (5) spring to autumn; and (6) summer to autumn. Seasonal change in the shoreline resulted with the corresponding change in categories. The OLI data classifications were made by applying SVM classifier and due to its improved features, OLI data is found suitable for seasonal land cover classification and post classification change detection analysis.
\end{abstract}

\section{Introduction}

The Landsat-8 Operational Land Imager (OLI) was launched in 2013. Intended to provide timely and high quality visible and infrared data, Landsat-8 includes several new features compared to ALI and Landsat 7, specifically: (1) two sensors (30 m resolution with eight spectral bands) and a Thermal Infrared Scanner (TIRS) (100 m resolution with two thermal bands) [1]; (2) a new Coastal/Aerosol (CA) band and a Cirrus band; (3) improved technical superiority with more bits (i.e., 12 bits as compared to 8 bits) and an improved signal-tonoise (SNR) performance over ALI and Landsat-7 [2]; and (4) improved instrument design

\footnotetext{
*Corresponding author: wasim_pervaiz@pnec.nust.edu.pk, wasim_pervaiz@yahoo.com
} 
compared to ALI and Landsat 7 [3-5]. The width of OLI band 5 is refined to exclude atmospheric absorption features at 825 nanometers $(\mathrm{nm})$ and its panchromatic bandwidth is reduced to improve detection of vegetation vs. non-vegetation compared with previous Landsat series. In OLI, the new Cirrus band detects thin clouds more accurately compared to previous satellite-based sensors (i.e., ALI and Landsat-7) [6]. Landsat 8 provides regional monitoring through remote sensing with substantial improvements in data quality due to advances in its noise reduction and spectral coverage designs [7, 8]. Studying different satellite sensors and their parameters (i.e., scanning systems, sensor characteristics, data systems, resolution, and so on) is important. However, studies examining the characteristics of Landsat-8 and its pre- and post-flight calibrations are rare in the literature [9-15].

Change detection remains a challenging problem and is used different for classification and change detection analysis [16-18]. Different satellite based change detection methods have different advantages and disadvantages $[19,20]$. In some change detection methods, no training data is required [21] e.g., in image differences [22] and clustering based methods [23] provide only change vs no change. If training data is available, then post classification change detection analysis [24] supervised change vector analysis [25, 26] and direct classification [27] provide "from-to" information and are preferred methods. However, selecting a change detection method still depends heavily upon its intended application [2832]. Land use/cover change information is used for various applications [33]. Different change detection types include: urban land cover and change detection $[34,35]$ impervious surface change detection [36], land cover change detection [37, 38]. Post classification change detection analysis is one of the most applied techniques due to its advantages of minimizing environmental and atmospheric differences between images and matrix of change detection. Hence this technique is applied in this paper.

ALI (30 m resolution with nine spectral bands) has a swath width of $37 \mathrm{~km}$ and lower technical superiority than OLI but better technical superiority than Landsat-7 [6, 39-42]. Hyperion (30 m resolution with 12 bits) has a swath width of $7.7 \mathrm{~km}$ and a swath length of $185 \mathrm{~km}$ and contains hundreds of bands, but it requires atmospheric correction during preprocessing [43, 44]. IKONOS, Quick Bird and WorldView-2 are useful in applications that have detailed image spatial requirements; however, their sensors have limitations for long-term or regular monitoring over large areas [45-47]. Hyperspectral remote sensing, due to its technical characteristics, has been considered suitable for use in mapping applications [48-65]. Classifiers for mapping application can be categorized as iterative and non-iterative. SVM is an iterative classifier, and is superior to SAM [66, 67] and SID classifiers which are non-iterative [68]. The SVM classifier provides better results even when only small amounts of training data are available or with high-dimensional data, because it focuses on training data near class boundaries [69-72].

This study conducted satellite-based change detection analysis using Landsat-8 OLI images. The main goals of this paper were: (i) to evaluate the results of SVM classifications on OLI data over four different seasons (i.e., spring, autumn, winter, and summer) after preprocessing and atmospheric correction; (ii) to use the post-classification change detection results from OLI SVM-classified data of four seasons to perform a change detection analysis of six cases: (1) from winter to spring, (2) winter to summer, (3) winter to autumn, (4) spring to summer, (5) spring to autumn, and (6) summer to autumn; (iii) to compare the classification accuracies achieved on the OLI data by applying SVM classifier. 


\section{Study area, sensors, and its characteristics}

This study's main objective was to perform change detection analysis and mapping of the study area (Figure 1). The study area was classified into six distinct classes (i.e., bare soil, built-up area, mixed forest, shrub, deep water and shallow water). Table 1 shows the imaging geometry conditions, sensor altitude, sun azimuth, sun elevation, and scene center latitude and longitude for the Landsat-8 OLI, ALI, and Hyperion satellites. Table 2 shows the band names, wavelengths, center wave length, ground resolution, and swath width of the Landsat8, ALI and Hyperion bands [73-75]. Excluded from this study are the OLI panchromatic and cirrus bands, the ALI, and the Hyperion bands. Landsat- 8 data covering four seasons (i.e., autumn, summer, spring and winter) were acquired and used for change detection analysis (Table 3).

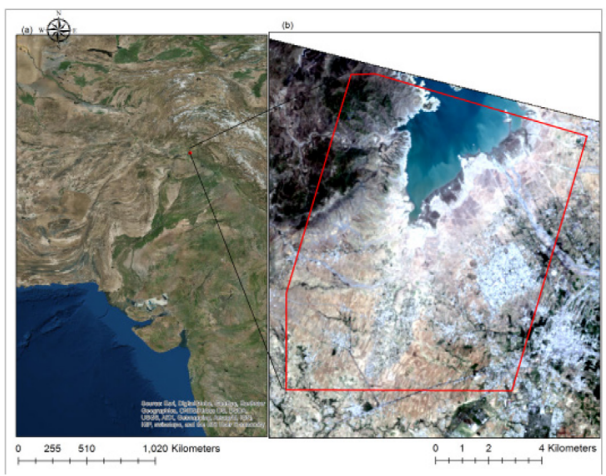

Fig. 1. (a) Study area location (regional) and (b) study area (outlined in red).

Table 1 Imaging geometry conditions and scene center latitudes and longitudes for Landsat- 8

\begin{tabular}{|c|c|c|c|c|}
\hline & $\begin{array}{c}\text { L8 OLI }^{\mathrm{a}} \\
22 \text { October } \\
2015\end{array}$ & $\begin{array}{c}\text { L8 OLI }^{\mathrm{a}} \\
16 \text { June, } \\
2015\end{array}$ & $\begin{array}{c}\text { L8 OLI } \\
13 \text { April, } \\
2015\end{array}$ & $\begin{array}{c}\text { L8 OLI }^{\text {a }} \\
6 \text { December, } \\
2014\end{array}$ \\
\hline Sensor Altitude & $705 \mathrm{~km}$ & $705 \mathrm{~km}$ & $705 \mathrm{~km}$ & $705 \mathrm{~km}$ \\
\hline Off-nadir/Nadir & Nadir & Nadir & Nadir & Nadir \\
\hline Sun Azimuth & $156.08^{\circ}$ & $111.55^{\circ}$ & $135.07^{\circ}$ & $159.10^{\circ}$ \\
\hline Sun Elevation & $42.78^{\circ}$ & $68.45^{\circ}$ & $58.58^{\circ}$ & $31.57^{\circ}$ \\
\hline Scene center latitude & $33.17^{\circ}$ & $33.27^{\circ}$ & $33.17^{\circ}$ & $33.17^{\circ}$ \\
\hline Scene center longitude & $72.88^{\circ}$ & $72.87^{\circ}$ & $72.85^{\circ}$ & $72.88^{\circ}$ \\
\hline
\end{tabular}

a. L8 OLI = Landsat-8 Operational Land Imager

Table 2. Characteristics and center wavelength Landsat 8, ALI, and Hyperion sensors [73-75]

\begin{tabular}{|c|c|c|c|c|c|c|}
\hline $\begin{array}{c}\text { Band } \\
\text { Name }\end{array}$ & $\begin{array}{c}\text { Band } \\
\text { Number }\end{array}$ & $\begin{array}{c}\text { Wavelength } \\
(\mathrm{nm})\end{array}$ & $\begin{array}{c}\mathrm{CW}^{\mathrm{a}} \\
(\mathrm{nm})\end{array}$ & $\begin{array}{c}\text { Band } \\
\text { width } \\
(\mathrm{nm})\end{array}$ & $\begin{array}{c}\text { Ground } \\
\text { Resolution } \\
(\mathrm{m})\end{array}$ & $\begin{array}{c}\text { Swath } \\
\text { Width } \\
(\mathrm{km})\end{array}$ \\
\hline \multicolumn{7}{|l|}{ Landsat-8 sensor } \\
\cline { 1 - 3 } $\begin{array}{c}\text { Coastal/ } \\
\text { Aerosol }\end{array}$ & 1 & $433-453$ & 443 & 20 & 30 & 185 \\
\hline Blue & 2 & $450-515$ & 482 & 65 & & \\
\hline Green & 3 & $525-600$ & 562 & 75 & & \\
\hline
\end{tabular}




\begin{tabular}{|c|c|c|c|c|c|c|}
\hline Red & 4 & $630-680$ & 655 & 50 & & \\
\hline NIR & 5 & $845-885$ & 865 & 40 & & \\
\hline SWIR-1 & 6 & $1560-1660$ & 1610 & 100 & & \\
\hline SWIR-2 & 7 & $2100-2300$ & 2200 & 200 & & \\
\hline Pan & 8 & $500-680$ & 590 & 180 & 15 & \\
\hline Cirrus & 9 & $1360-1390$ & 1375 & 30 & 30 & \\
\hline TIR-1 & 10 & $10300-11300$ & 10800 & 1000 & \multirow[t]{2}{*}{100} & \\
\hline TIR-2 & 11 & $11500-12500$ & 12000 & 1000 & & \\
\hline \multicolumn{7}{|c|}{$\underline{\text { ALI sensor }}$} \\
\hline Pan & 10 & $480-690$ & 585 & 210 & 10 & \multirow[t]{10}{*}{37} \\
\hline Blue & 1 & $433-453$ & 443 & 20 & \multirow[t]{9}{*}{30} & \\
\hline Blue1 & 2 & $450-515$ & 482 & 65 & & \\
\hline Green & 3 & $525-605$ & 565 & 80 & & \\
\hline Red & 4 & $633-690$ & 662 & 67 & & \\
\hline NIR-1 & 5 & $775-805$ & 790 & 30 & & \\
\hline NIR-2 & 6 & $845-890$ & 867 & 45 & & \\
\hline SWIR-1 & 7 & $1200-1300$ & 1250 & 100 & & \\
\hline SWIR & 8 & $1550-1750$ & 1650 & 200 & & \\
\hline SWIR & 9 & $2080-2350$ & 2215 & 270 & & \\
\hline \multicolumn{7}{|c|}{ Hyperion sensor } \\
\hline VNIR & $1-70$ & $355-1057$ & 706 & 702 & \multirow[t]{2}{*}{30} & \multirow[t]{2}{*}{7.7} \\
\hline SWIR & $71-242$ & $851-2577$ & 1714 & 1726 & & \\
\hline
\end{tabular}

a. VNIR $=$ visible-infrared, SWIR $=$ short-wave infrared, and TIR $=$ thermal infra-red, $\mathrm{CW}=$ center wavelength

Table 3. Landsat- 8 data for four seasons acquired for change detection analysis

\begin{tabular}{|c|c|c|}
\hline Season & Date of Acquisition & $\begin{array}{c}\text { Landsat-8 } \text { OLI }^{\mathrm{a}} \\
\text { (Path/Row 150/37) }\end{array}$ \\
\hline Autumn & 22 October, 2015 & LC81500372015295LGN00 \\
\hline Summer & 16 June, 2015 & LC81500372015167LGN00 \\
\hline Spring & 13 April, 2015 & LC815003720015103LG00 \\
\hline Winter & 6 December, 2014 & LC81500372014340LG00 \\
\hline
\end{tabular}

a. OLI = Operational Land Imager

\section{Data preprocessing}

\subsection{Atmospheric correction of OLI data}

OLI data was pre processed by atmospherically correction and conversion to reflectance values [76-78]. Previous studies used different techniques for pre processing of satellite 
imagery [79-87]. This study used FLAASH to perform atmospheric correction of OLI images.

\section{Results and discussion}

\subsection{Support vector machines design}

The SVM classifier is used to determine a decision function [42]. Linear SVM is used to separate linearly separable classes. When training data is represented by $\mathrm{x}_{\mathrm{i}}$ (with $\mathrm{n}$ numbers of samples), then $\mathrm{y}_{\mathrm{i}}, \mathrm{i}=1,2 \ldots \mathrm{n}$ represents the corresponding classes, such that $\mathrm{y} \in\{-1,+1\}$ Case 1: For two-dimensional data, the spatial function is shown in Equation 1:

$$
f(X)=m \cdot x+c,
$$

where $\mathrm{m}$ is a vector used to orient the differentiating/dividing plane and $\mathrm{c}$ is a scalar that determines the offset of the discriminating plane.

When $m \cdot x+c>0, \mathrm{x}_{\mathrm{i}}$ is assigned to the $1^{\text {st }}$ class, while when $m \cdot x+c<0, \mathrm{x}_{\mathrm{i}}$ belongs to the $2^{\text {nd }}$ class. When $|\mathrm{f}(\mathrm{x})| \geq 1$, the classification interval $\left(2 /\|\mathrm{m}\|,\|\mathrm{m}\|\right.$ or $\left.\|\mathrm{m}\|^{2}\right)$ will be the smallest. Equation (2) shows the optimal function:

$$
\operatorname{Min}_{m}=1 / 2\|m\|^{2}=1 / 2(m . m),
$$

this should satisfy Equation (3) to maximize the classification margin and thus form the optimal hyper plane, L:

$$
y_{i}(m \cdot x+c)-1 \geq 0, \quad i=1,2, \ldots . n \text {. }
$$

Equation (4) defines the space denoted by the set of functions for hyperplanes L1 and L2:

$$
f_{m, c}=\operatorname{sign}(m \cdot x+c) \text {. }
$$

For a nonlinear case of the dual optimization problem, Equation 5 is used:]

$$
\max L_{(w, c, \gamma)}=\sum_{i=1}^{k} \gamma_{i}-1 / 2 \sum_{i=1}^{k} \sum_{j=1}^{k} \gamma_{i} \gamma_{j} y_{i} y_{j} K\left(x_{i} \cdot x_{j}\right),
$$

subject to the following constraints:

$$
\sum_{i=1}^{k} \gamma_{i} y_{i}=0 \text { and } \mathrm{C} \geq \gamma_{\mathrm{i}} \geq 0 .
$$

The penalty parameter $(C)$ and the kernel parameter $(\gamma)$ values were set to optimum values for the radial basis function (RBF).

\subsection{Operational land imager support vector machine classifications and change detection analysis}

\subsubsection{Experimental Setup}

The pixel-based supervised classifier (i.e., SVM ) was implemented on OLI data e.g., Figure 2) acquired on 22 Oct, 2015 (Autumn), 16 June, 2015 (Summer), 13 April, 2015 (Spring) and 6 December, 2014 (Winter) using the following steps:

Step 1: Identifying and formulating six classes in the study area.

Step 2: Selection of the regions of interest (ROIs) from the image data, which included 202 samples (6 partitions) of bare soil, 243 samples (2 partitions) of built-up area, 62 samples ( 2 partitions) of mixed forest, 47 samples ( 2 partitions) of shrub, 278 samples ( 5 partitions) of 
deep water and 69 samples (4 partitions) of shallow water. These ROIs and reference data were selected using several different methods: (1) surveys of Pakistan maps, (2) high resolution (1 m resolution) panchromatic OrbView-3 imagery, (3) high resolution ALI panchromatic data (10 m spatial resolution), (4) high resolution Google Earth software, (5) acquaintance with the study area, (6) selected field visits, and (7) prominent and consistent land use/cover locations (8) high resolution Sentinel 2 imagery (9) analysis of original Landsat imageries.

Step 3: For the OLI data, using the SVM classifier, the following values were assigned to parameters: kernel parameter gamma $(\gamma)=0.143$ was calculated as inverse of the number of bands, penalty parameter $\mathrm{C}=100$ maximum value so that all training pixels to be assigned certain class, pyramid parameter $=$ zero value to process imagery at full resolution, and the classification probability threshold = zero to assign entire pixel to certain class.

The OLI data were classified (Figure 2) using the SVM classifier for all four seasons (i.e., winter, spring, summer and autumn). Figure 2 (a) to (d) shows the land use/land cover classifications from the Landsat-8 Operational Land Imager (OLI) data for winter (6 December, 2014), spring (13 April, 2015), summer (16 June, 2015), and Autumn (22 October, 2015) made by the SVM classifier. The OLI classified data for the four seasons were used to perform change detection analysis for six cases: (1) winter to spring; (2) winter to summer; (3) winter to autumn; (4) spring to summer; (5) spring to autumn; (6) summer to autumn.

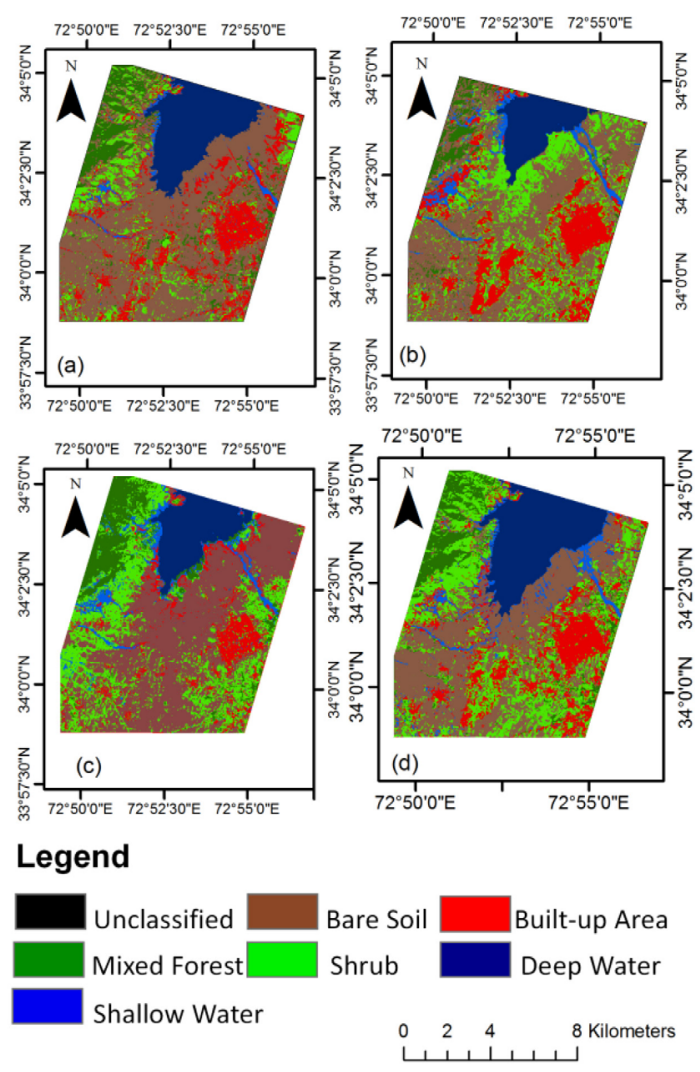

Fig. 2. Land use/land cover classifications of Landsat-8 Operational Land Imager (OLI) data made with the support vector machine (SVM) classifier (a) winter (6 December, 2014), (b) spring (13 April, 2015) (c) summer (16 June, 2015), and (d) autumn (22 October, 2015) 


\subsubsection{Change detection from winter to spring (case 1)}

The change detection technique was implemented in ENVI and executed on SVM-classified data of Landsat-8 OLI from winter (6 December, 2014) to spring (13 April, 2015). In the change detection analysis from winter to spring, it is found from the change detection matrix (Table 4), decrease of spatial extensions of deep water $34.45 \%$, bare soil $15.92 \%$, mixed forest $44.97 \%$ and increase of shallow water $141.63 \%$, shrub $109.75 \%$ and built-up area $31.21 \%$. The major shoreline change detection analysis from winter to spring (Figure 3) shows a change of category with a reduction in dam water mapping from deep water to shallow water, deep water to shrub, and deep water to bare soil. These changes are due to shrub increases in spring compared to winter. Similarly, a change of category from bare soil to shrub resulted from shrub increases in spring as compared to winter. A change of category from bare soil to shallow water and shrub to shallow water near the shoreline resulted from an increase in shallow water in the channels in spring as compared to winter.

Table 4. Landsat-8 Operational Land Imager (OLI) data change detection percentage from winter to spring (case1)

\begin{tabular}{|l|c|c|c|c|c|c|}
\hline Class & Bare Soil & $\begin{array}{c}\text { Built-up } \\
\text { Area }\end{array}$ & $\begin{array}{c}\text { Mixed } \\
\text { Forest }\end{array}$ & Shrub & $\begin{array}{c}\text { Deep } \\
\text { Water }\end{array}$ & $\begin{array}{c}\text { Shallow } \\
\text { Water }\end{array}$ \\
\hline Bare Soil & 64.90 & 17.44 & 44.39 & 25.48 & 8.85 & 4.58 \\
\hline Built-up Area & 6.74 & 64.39 & 0.88 & 31.11 & 0.52 & 7.16 \\
\hline Mixed Forest & 1.81 & 0.14 & 40.78 & 0.23 & 0.69 & 0.00 \\
\hline Shrub & 24.82 & 11.08 & 13.45 & 39.29 & 20.73 & 7.54 \\
\hline Deep Water & 0.00 & 0.05 & 0.10 & 0.00 & 65.42 & 0.05 \\
\hline Shallow Water & 1.71 & 6.89 & 0.40 & 3.88 & 3.78 & 80.67 \\
\hline Class Total & 100.00 & 100.00 & 100.00 & 100.00 & 100.00 & 100.00 \\
\hline Class Changes & 35.09 & 35.60 & 59.22 & 60.70 & 34.58 & 19.33 \\
\hline $\begin{array}{l}\text { Image } \\
\text { Difference }\end{array}$ & -15.92 & 13.21 & -44.97 & 109.75 & -34.45 & 141.63 \\
\hline
\end{tabular}




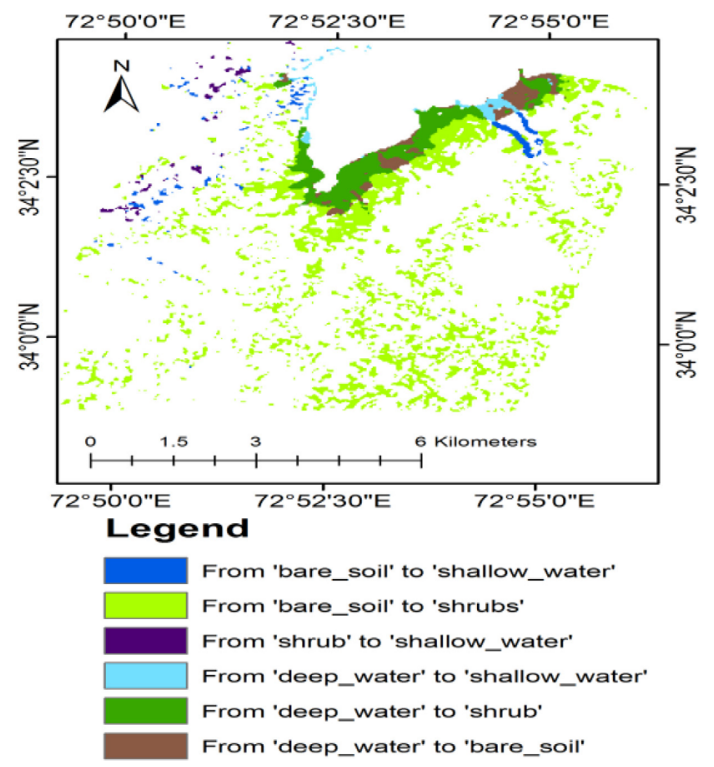

Fig.. 3 Change detection results of Landsat-8 Operational Land Imager (OLI) data using the support vector machine (SVM) classifier from (a) winter (6 December, 2014) to (b) spring (13 April, 2015)

\subsubsection{Change detection from winter to summer (case 2)}

The change detection technique was implemented in ENVI and executed on SVM-classified data of Landsat-8 OLI from winter (6 December, 2014) to summer (16 June, 2015). In the change detection analysis from winter to summer, it is found from the change detection matrix (Table 5), decrease of spatial extensions of deep water $30.49 \%$, bare soil $15.04 \%$, built-up area $39.90 \%$ and increase of shallow water $187.34 \%$, shrub $119.12 \%$ and mixed forest $20.14 \%$. The major shoreline change detection analysis from winter to summer (Figure 4) shows a change of category with a reduction in dam water mapping from deep water to shallow water, deep water to shrub, deep water to bare soil and deep water to mixed forest. These changes are due to shrub and mixed forest increases in summer compared to winter. Similarly, a change of category from bare soil to shrub and bare soil to mixed forest resulted from shrub and mixed forest increases in summer compared to winter. A change of category from bare soil to shallow water near the shoreline was due to an increase of shallow water in the channels during the summer compared to winter.

Table 5. Landsat- 8 Operational Land Imager (OLI) data change detection percentage from winter to summer (case2)

\begin{tabular}{|l|c|c|c|c|c|c|}
\hline Class & Bare Soil & $\begin{array}{c}\text { Built-up } \\
\text { Area }\end{array}$ & $\begin{array}{c}\text { Mixed } \\
\text { Forest }\end{array}$ & Shrub & $\begin{array}{c}\text { Deep } \\
\text { Water }\end{array}$ & $\begin{array}{c}\text { Shallow } \\
\text { Water }\end{array}$ \\
\hline Bare Soil & 60.02 & 42.52 & 10.26 & 47.78 & 5.27 & 3.773 \\
\hline Built-up Area & 3.64 & 37.93 & 0.25 & 2.20 & 6.31 & 13.35 \\
\hline Mixed Forest & 4.00 & 0.56 & 69.70 & 6.94 & 6.64 & 1.4 \\
\hline Shrub & 29.99 & 12.78 & 18.59 & 39.17 & 4.42 & 2.26 \\
\hline Deep Water & 0.00 & 0.00 & 0.05 & 0.00 & 69.46 & 0.11 \\
\hline
\end{tabular}




\begin{tabular}{|l|c|c|c|c|c|c|}
\hline $\begin{array}{l}\text { Shallow } \\
\text { Water }\end{array}$ & 2.35 & 6.20 & 1.13 & 3.89 & 7.78 & 79.11 \\
\hline Class Total & 100.00 & 100.00 & 100.00 & 100.00 & 100.00 & 100.00 \\
\hline $\begin{array}{l}\text { Class } \\
\text { Changes }\end{array}$ & 39.98 & 62.07 & 30.29 & 60.83 & 30.54 & 20.89 \\
\hline $\begin{array}{l}\text { Image } \\
\text { Difference }\end{array}$ & -15.04 & -39.90 & 20.14 & 119.12 & -30.49 & 187.34 \\
\hline
\end{tabular}
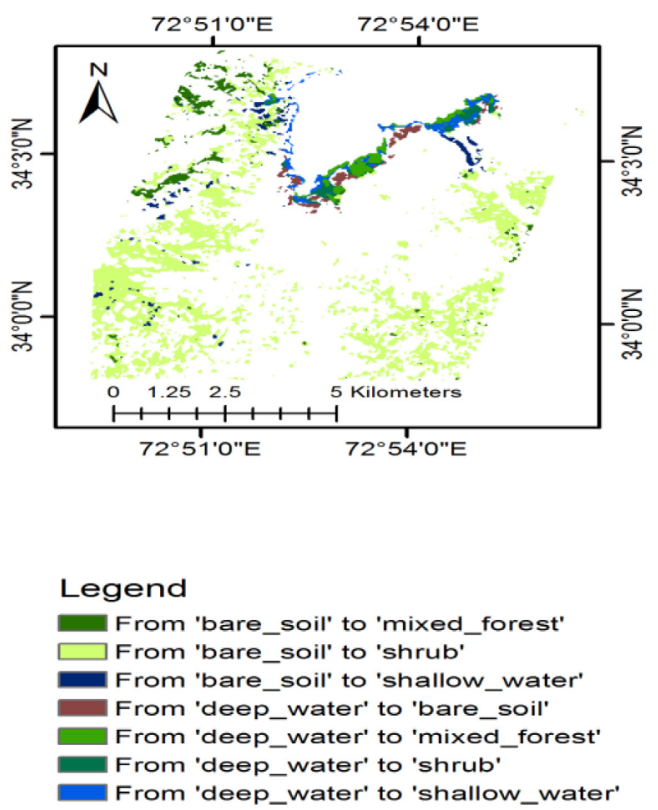

Fig. 4. Change detection of Landsat-8 Operational Land Imager (OLI) data using the support vector machine (SVM) classifier from (a) winter (6 December, 2014) to (b) summer (16 June, 2015)

\subsubsection{Change detection from winter to autumn (case 3)}

The change detection technique was implemented in ENVI and executed on SVM-classified data of Landsat-8 OLI from winter (6 December, 2014) to autumn (22 October, 2015). In the change detection analysis from winter to autumn, it is found from the change detection matrix (Table 6), decrease of spatial extensions of mixed forest $6.47 \%$, bare soil $31.32 \%$ and increase of shallow water $144.37 \%$, deep water $12.86 \%$, shrub $113.32 \%$ and built-up area $1.23 \%$. The major shoreline change detection analysis (Figure 5) shows category changes with little increase in dam water mapping from bare soil to deep water and from bare soil to shallow water in area near the shoreline. Similarly, category changes from mixed forest to shrub resulted from winter to autumn season.

Table 6. Landsat- 8 Operational Land Imager (OLI) data change detection percentage from winter to autumn (case3) 


\begin{tabular}{|l|c|c|c|c|c|c|}
\hline Class & Bare Soil & $\begin{array}{c}\text { Built-up } \\
\text { Area }\end{array}$ & $\begin{array}{c}\text { Mixed } \\
\text { Forest }\end{array}$ & Shrub & $\begin{array}{c}\text { Deep } \\
\text { Water }\end{array}$ & $\begin{array}{c}\text { Shallow } \\
\text { Water }\end{array}$ \\
\hline Bare Soil & 58.99 & 15.08 & 12.19 & 16.08 & 0.17 & 7.59 \\
\hline Built-up Area & 5.95 & 69.26 & 0.34 & 12.88 & 0.00 & 9.04 \\
\hline Mixed Forest & 2.38 & 0.01 & 76.34 & 0.65 & 0.00 & 0.00 \\
\hline Shrub & 25.92 & 9.16 & 10.25 & 69.29 & 0.00 & 1.40 \\
\hline Deep Water & 3.23 & 0.01 & 0.39 & 0.00 & 99.80 & 2.96 \\
\hline Shallow Water & 3.52 & 6.47 & 0.48 & 1.10 & 0.03 & 78.99 \\
\hline Class Total & 100.00 & 100.00 & 100.00 & 100.00 & 100.00 & 100.00 \\
\hline Class Changes & 41.01 & 30.74 & 23.65 & 30.71 & 0.19 & 21.00 \\
\hline Image Difference & -31.32 & 1.23 & -6.467 & 113.32 & 12.86 & 144.37 \\
\hline
\end{tabular}

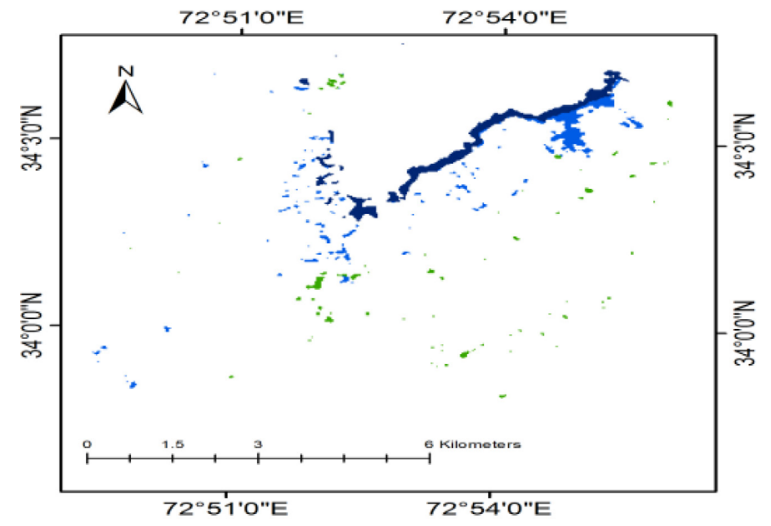

\section{Legend}

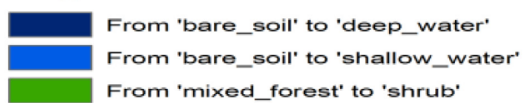

Fig. 5. Change detection of Landsat- 8 Operational Land Imager (OLI) data using the support vector machine (SVM) classifier from (a) winter (6 December, 2014) to (b) autumn (22 October, 2015)

\subsubsection{Change detection from spring to summer (case 4)}

The change detection technique was implemented in ENVI and executed on SVM-classified data of Landsat-8 OLI from spring (13 April, 2015) to summer (16 June, 2015). In the change detection analysis from spring to summer, it is found from the change detection matrix (Table 7), decrease of spatial extensions of built-up area $46.92 \%$ and increase of shallow water 18.92 $\%$, deep water $6.04 \%$, shrub $4.46 \%$, mixed forest $118.315 \%$ and bare soil $1.03 \%$. The major shoreline change detection analysis (Figure 6) shows category changes with very little increase in dam water mapping from bare soil to deep water and from bare soil to shallow water in areas near the shoreline from spring to summer. Similarly, category changes from 
shrub to bare soil and shrub to shallow water resulted from conversion of shrub to bare soil and shallow water respectively from spring to summer.

Table 7. Landsat-8 Operational Land Imager (OLI) data change detection percentage from spring to summer (case4)

\begin{tabular}{|l|c|c|c|c|c|c|}
\hline Class & Bare Soil & $\begin{array}{c}\text { Built-up } \\
\text { Area }\end{array}$ & $\begin{array}{c}\text { Mixed } \\
\text { Forest }\end{array}$ & Shrub & $\begin{array}{c}\text { Deep } \\
\text { Water }\end{array}$ & $\begin{array}{c}\text { Shallow } \\
\text { Water }\end{array}$ \\
\hline Bare Soil & 59.09 & 37.50 & 11.64 & 50.80 & 0.00 & 1.87 \\
\hline Built-up Area & 2.81 & 34.70 & 1.28 & 6.41 & 0.00 & 7.02 \\
\hline Mixed Forest & 10.56 & 0.29 & 75.90 & 4.21 & 0.07 & 7.76 \\
\hline Shrub & 25.18 & 25.01 & 7.66 & 34.53 & 0.00 & 10.14 \\
\hline Deep Water & 0.59 & 0.00 & 1.76 & 0.53 & 99.85 & 2.25 \\
\hline Shallow Water & 1.76 & 2.48 & 1.76 & 3.50 & 0.07 & 70.96 \\
\hline Class Total & 100.00 & 100.00 & 100.00 & 100.00 & 100.00 & 100.00 \\
\hline Class Changes & 40.90 & 65.29 & 24.09 & 65.46 & 0.15 & 29.03 \\
\hline Image Difference & 1.03 & -46.92 & 118.31 & 4.46 & 6.04 & 18.92 \\
\hline
\end{tabular}

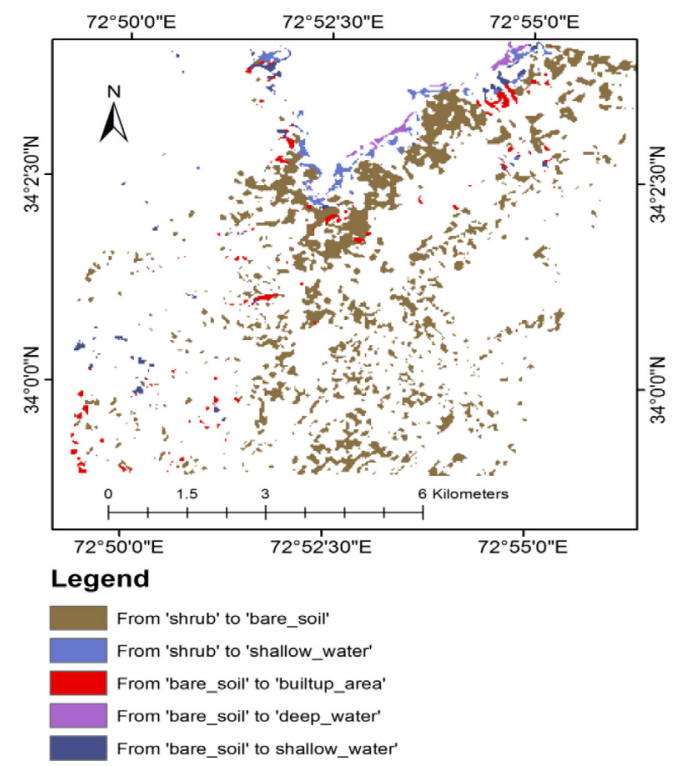

Fig. 6. Change detection of Landsat- 8 Operational Land Imager (OLI) data using the support vector machine (SVM) classifier from (a) spring (13 April, 2015) to (b) summer (16 June, 2015)

\subsubsection{Change detection from spring to autumn (case 5)}

The change detection technique was implemented in ENVI and executed on SVM-classified data of Landsat-8 OLI from spring (13 April, 2015) to autumn (22 Oct 2015). In the change detection analysis from spring to autumn, it is found from the change detection matrix (Table 8 ), decrease of spatial extensions of bare soil $18.32 \%$, built-up area $10.59 \%$ and increase of shallow water $1.14 \%$, deep water $72.20 \%$, shrub $1.7 \%$ and mixed forest $69.96 \%$. The major 
shoreline change detection analysis (Figure 7) shows category changes with increases in dam water mapping from shrub to deep water, bare soil to deep water and from shallow water to deep water in areas near the shoreline. These changes were due to a decrease in shrub from spring to autumn. Similarly, a small category change from shrub to bare soil was due to the decrease of shrub from spring to autumn.

Table 8. Landsat-8 Operational Land Imager (OLI) data change detection percentage from spring to autumn (case5)

\begin{tabular}{|l|c|c|c|c|c|c|}
\hline Class & Bare Soil & $\begin{array}{c}\text { Built-up } \\
\text { Area }\end{array}$ & $\begin{array}{c}\text { Mixed } \\
\text { Forest }\end{array}$ & Shrub & $\begin{array}{c}\text { Deep } \\
\text { Water }\end{array}$ & $\begin{array}{c}\text { Shallow } \\
\text { Water }\end{array}$ \\
\hline Bare Soil & 61.03 & 5.11 & 21.08 & 29.34 & 0.02 & 14.49 \\
\hline Built-up Area & 3.09 & 65.99 & 0.18 & 8.46 & 0.00 & 13.86 \\
\hline Mixed Forest & 7.75 & 0.179 & 73.50 & 2.70 & 0.02 & 0.11 \\
\hline Shrub & 20.65 & 27.19 & 1.80 & 39.18 & 0.00 & 14.29 \\
\hline Deep Water & 3.88 & 0.50 & 2.30 & 17.29 & 99.85 & 13.94 \\
\hline Shallow Water & 3.60 & 1.00 & 1.12 & 3.02 & 0.11 & 43.28 \\
\hline Class Total & 100.00 & 100.00 & 100.00 & 100.00 & 100.00 & 100.00 \\
\hline Class Changes & 38.97 & 34.00 & 26.49 & 60.82 & 0.15 & 56.72 \\
\hline Image Difference & -18.32 & -10.59 & 69.96 & 1.7 & 72.20 & 1.14 \\
\hline
\end{tabular}

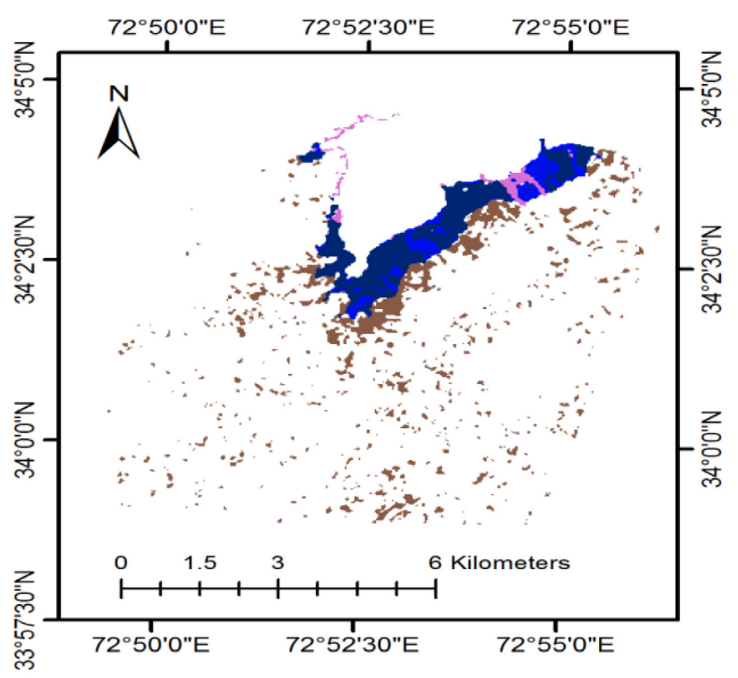

\footnotetext{
Legend

From 'shallow_water' to 'deep_water'

From 'shrub' to 'bare_soil'

From 'shrub' to 'deep_water'

From 'bare_soil' to 'deep_water'
} 
Fig. 7. Change detection of Landsat-8 Operational Land Imager (OLI) data classified using the support vector machine (SVM) classifier from (a) spring (13 April, 2015) to (b) autumn (22 October, 2015)

\subsubsection{Change detection from summer to autumn (case 6)}

The change detection technique was implemented in ENVI and executed on SVM-classified data of Landsat-8 OLI from summer (16 June, 2015) to autumn (22 Oct 2015). In the change detection analysis from spring to autumn, it is found from the change detection matrix (Table 9), decrease of spatial extensions of bare soil $19.15 \%$, mixed forest $22.15 \%$, shrub $2,65 \%$, deep water $62.39 \%$, shallow water $14.96 \%$ and increase of built-up area $68.44 \%$. The major shoreline change detection analysis (Figure 8 ) shows a category changes with an increase in dam water mapping from shrub to deep water, bare soil to deep water and from shallow water to deep water in areas near the shoreline. The changes are due to decreases of shrubs and bare soil from summer to autumn. Similarly, category changes from shrub to bare soil, mixed forest to shrub and mixed forest to deep water were the result of conversions of shrub and mixed forest areas to bare soil and shrub/mixed forest areas from summer to autumn. A small change of category from bare soil to shallow water resulted from changes of some bare soil to shallow water near the shoreline from summer to autumn. A change of category from bare soil to deep water resulted from the conversion of bare soil to deep water from summer to autumn near the shoreline.

Table 9. Landsat-8 Operational Land Imager (OLI) data change detection percentage from summer to autumn (case6)

\begin{tabular}{|l|c|c|c|c|c|c|}
\hline Class & Bare Soil & $\begin{array}{c}\text { Built-up } \\
\text { Area }\end{array}$ & $\begin{array}{c}\text { Mixed } \\
\text { Forest }\end{array}$ & Shrub & $\begin{array}{c}\text { Deep } \\
\text { Water }\end{array}$ & $\begin{array}{c}\text { Shallow } \\
\text { Water }\end{array}$ \\
\hline Bare Soil & 56.93 & 11.54 & 4.62 & 34.18 & 0.00 & 19.66 \\
\hline Built-up Area & 13.98 & 64.57 & 0.65 & 9.67 & 0.00 & 11.79 \\
\hline Mixed Forest & 0.14 & 0.00 & 61.28 & 6.06 & 0.00 & 0.19 \\
\hline Shrub & 21.3 & 2.46 & 22.56 & 46.01 & 0.00 & 10.06 \\
\hline Deep Water & 3.96 & 14.60 & 10.15 & 2.99 & 99.97 & 23.37 \\
\hline Shallow Water & 3.69 & 6.82 & 0.74 & 1.09 & 0.03 & 34.93 \\
\hline Class Total & 100.00 & 100.00 & 100.00 & 100.00 & 100.00 & 100.00 \\
\hline Class Changes & 43.07 & 35.43 & 38.72 & 53.99 & 0.03 & 65.07 \\
\hline Image Difference & -19.15 & 68.44 & -22.15 & -2.65 & 62.39 & -14.96 \\
\hline
\end{tabular}



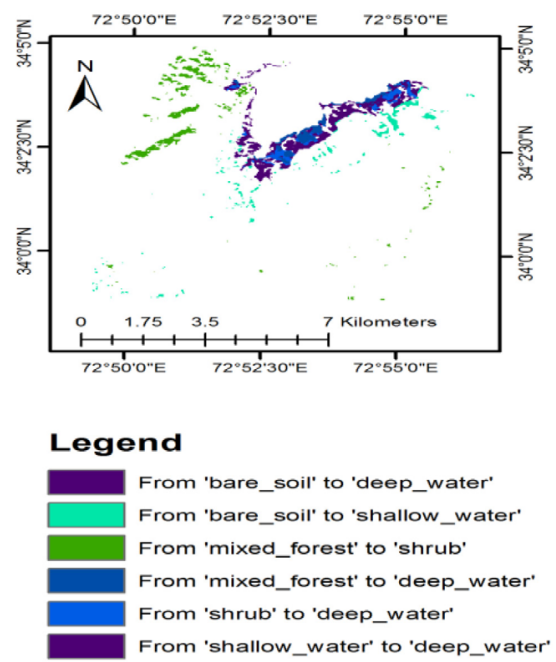

Fig. 8. Change detection of Landsat- 8 Operational Land Imager (OLI) data classified using the support vector machine (SVM) classifier from (a) summer (16 June, 2015) to (b) autumn (22 October, 2015).

\subsection{Classification accuracy}

Classification accuracy was assessed based on the confusion matrix on the OLI data (for the SVM classifier) half the samples were used as test points, resulting in an overall accuracy and kappa coefficient (Tables 10-13).

Table 10. Landsat-8 Operational Land Imager (OLI) performance winter data using support vector machine (SVM) vs. the ground truth $(\%)^{\mathrm{a}}$

\begin{tabular}{|l|c|c|c|c|c|c|}
\hline Class & Bare Soil & $\begin{array}{c}\text { Built-up } \\
\text { Area }\end{array}$ & $\begin{array}{c}\text { Mixed } \\
\text { Forest }\end{array}$ & Shrub & $\begin{array}{c}\text { Deep } \\
\text { Water }\end{array}$ & $\begin{array}{c}\text { Shallow } \\
\text { Water }\end{array}$ \\
\hline Bare Soil & 99.54 & 4.53 & 0.00 & 19.61 & 0.00 & 0.00 \\
\hline Built-up Area & 0.46 & 94.65 & 0.00 & 1.96 & 0.00 & 17.65 \\
\hline Mixed Forest & 0.00 & 0.00 & 98.39 & 7.84 & 0.00 & 0.00 \\
\hline Shrub & 0.00 & 0.00 & 1.61 & 70.59 & 0.00 & 0.00 \\
\hline Deep Water & 0.00 & 0.00 & 0.00 & 0.00 & 100.00 & 0.00 \\
\hline Shallow Water & 0.00 & 0.82 & 0.00 & 0.00 & 0.00 & 82.35 \\
\hline Total & 100.00 & 100.00 & 100.00 & 100.00 & 100.00 & 100.00 \\
\hline
\end{tabular}

a. Overall Accuracy $=95 \%$, Kappa Coefficient $=0.94$ 
Table 11. Landsat-8 Operational Land Imager (OLI) performance spring data using support vector machine (SVM) vs. the ground truth $(\%)^{\mathrm{a}}$

\begin{tabular}{|l|c|c|c|c|c|c|}
\hline Class & Bare Soil & $\begin{array}{c}\text { Built-up } \\
\text { Area }\end{array}$ & $\begin{array}{c}\text { Mixed } \\
\text { Forest }\end{array}$ & Shrub & $\begin{array}{c}\text { Deep } \\
\text { Water }\end{array}$ & $\begin{array}{c}\text { Shallow } \\
\text { Water }\end{array}$ \\
\hline Bare Soil & 99.11 & 0.00 & 22.58 & 0.00 & 0.00 & 2.94 \\
\hline Built-up Area & 0.00 & 99.18 & 0.00 & 0.00 & 0.00 & 1.47 \\
\hline Mixed Forest & 0.89 & 0.00 & 77.42 & 0.00 & 0.00 & 0.00 \\
\hline Shrub & 0.00 & 0.82 & 0.00 & 98.04 & 0.00 & 0.00 \\
\hline Deep Water & 0.00 & 0.00 & 0.00 & 0.00 & 100.00 & 0.00 \\
\hline Shallow Water & 0.00 & 0.00 & 0.00 & 1.96 & 0.00 & 95.59 \\
\hline Total & 100.00 & 100.00 & 100.00 & 100.00 & 100.00 & 100.00 \\
\hline
\end{tabular}

a. Overall Accuracy $=97 \%$, Kappa Coefficient $=0.97$

Table 12. Landsat-8 Operational Land Imager (OLI) performance summer data using support vector machine (SVM) vs. the ground truth $(\%)^{\mathrm{a}}$

\begin{tabular}{|l|c|c|c|c|c|c|}
\hline Class & Bare Soil & $\begin{array}{c}\text { Built-up } \\
\text { Area }\end{array}$ & $\begin{array}{c}\text { Mixed } \\
\text { Forest }\end{array}$ & Shrub & $\begin{array}{c}\text { Deep } \\
\text { Water }\end{array}$ & $\begin{array}{c}\text { Shallow } \\
\text { Water }\end{array}$ \\
\hline Bare Soil & 97.52 & 3.29 & 0.00 & 6.38 & 0.00 & 0.00 \\
\hline Built-up Area & 0.00 & 89.71 & 0.00 & 0.00 & 0.00 & 10.14 \\
\hline Mixed Forest & 0.00 & 0.00 & 100.00 & 0.00 & 0.00 & 2.90 \\
\hline Shrub & 2.48 & 5.76 & 0.00 & 87.23 & 0.00 & 10.14 \\
\hline Deep Water & 0.00 & 0.00 & 0.00 & 0.00 & 100.00 & 0.00 \\
\hline Shallow Water & 0.00 & 1.23 & 0.00 & 6.38 & 0.00 & 76.81 \\
\hline Total & 100.00 & 100.00 & 100.00 & 100.00 & 100.00 & 100.00 \\
\hline
\end{tabular}

a. Overall Accuracy $=94 \%$, Kappa Coefficient $=0.92$

Table 13. Landsat-8 Operational Land Imager (OLI) performance autumn data using support vector machine (SVM) vs. the ground truth $(\%)^{\mathrm{a}}$

\begin{tabular}{|l|c|c|c|c|c|c|}
\hline Class & Bare Soil & $\begin{array}{c}\text { Built-up } \\
\text { Area }\end{array}$ & $\begin{array}{c}\text { Mixed } \\
\text { Forest }\end{array}$ & Shrub & $\begin{array}{c}\text { Deep } \\
\text { Water }\end{array}$ & $\begin{array}{c}\text { Shallow } \\
\text { Water }\end{array}$ \\
\hline Bare Soil & 99.53 & 0.00 & 0.00 & 0.00 & 0.00 & 0.00 \\
\hline Built-up Area & 0.00 & 99.59 & 0.00 & 1.96 & 0.00 & 4.41 \\
\hline Mixed Forest & 0.00 & 0.00 & 100.00 & 0.00 & 0.00 & 0.00 \\
\hline Shrub & 0.47 & 0.41 & 0.00 & 98.04 & 0.00 & 0.00 \\
\hline Deep Water & 0.00 & 0.00 & 0.00 & 0.00 & 100.00 & 0.00 \\
\hline Shallow Water & 0.00 & 0.00 & 0.00 & 0.00 & 0.00 & 91.18 \\
\hline Total & 100.00 & 100.00 & 100.00 & 100.00 & 100.00 & 100.00 \\
\hline
\end{tabular}

a. Overall Accuracy $=99 \%$, Kappa Coefficient $=0.98$

The overall accuracy and kappa coefficient for OLI data classifications with SVM were, respectively $94 \%$ and 0.94 for winter (Table 10), 97\% and 0.97 for spring (Table 11), and $94 \%$ and 0.92 for summer (Table 12) and $94 \%$ and 0.98 for autumn (Table 13). It is found 
(Table 10-13) that OLI data classifications with SVM resulted higher class discrimination accuracy, overall accuracy (more than 94\%) and kappa coefficient. Hence it is suitable for change detection analysis and mapping applications.

\section{Summary and conclusions}

The results of this study confirmed the potential utility of seasonal satellite based land cover classification of OLI data for all four seasons (i.e., autumn, summer, spring and winter) and post-classification change detection analysis. The OLI data (using SVM classifier) was successfully classified with regard to all six test classes (i.e., bare soil, built-up area, mixed forest, shrub, deep water and shallow water) after pre-processing and atmospheric correction. It is found (Table 10-13) that OLI data classifications with SVM resulted higher class discrimination accuracy, overall accuracy (more than 94\%) and kappa coefficient and thus suitable for mapping application.

The OLI SVM-classified data for four seasons i.e., winter (6 December, 2014), spring (13 April, 2015), summer (16 June, 2015), and autumn (22 Oct 2015) were used for change detection analysis of six cases: (1) winter to spring, (2) winter to summer, (3) winter to autumn, (4) spring to summer, (5) spring to autumn, and (6) summer to autumn. The major shoreline change detection analysis from winter to spring (case 1) resulted in an increase of shrub and the amount of shallow water in channels in spring as compared to winter and shows category changes with a reduction in dam water mapping. The major shoreline change detection analysis from winter to summer (case 2) resulted in increases of shrub, mixed forest categories and shallow water in the channels in summer as compared to winter and show category changes with the reduction in dam water. The major shoreline change detection analysis (case 3 ) resulted in a decrease of bare soil and mixed forest from winter to autumn and showed category changes with little increase in dam water mapping in areas near the shoreline. The major shoreline change detection analysis (case 4) resulted small change of bare soil due to conversions of shrub to bare soil and shallow water from spring to summer and showed category changes with very little increase in dam water mapping in areas near the shoreline. The major shoreline change detection analysis (case 5) resulted in a decrease of shrub due to conversion of shrub to deep water, bare soil to deep water, shallow water to deep water from spring to autumn and showed category changes with an increase in dam water mapping in areas near the shoreline. The major shoreline change detection analysis (case 6) resulted in a decrease of shrub, mixed forest and bare soil due to conversion of shrub and mixed forest to bare soil from summer to autumn and showed category changes with increases in dam water mapping in areas near the shoreline.

These results confirmed that the new OLI technology, with its superior radiometric performance and improved design, resulted in accurate inland water mapping and suitable for post classification change detection analysis. Remote sensing provides an important method of Earth observation and change detection analysis. The change in dam water reservoir capacity determined from the OLI data due to seasonal change was clearly shown during the water classification. In conclusion, the improved OLI technology is both suitable for post-classification change detection analysis and resulted in accurate mapping of the study area.

The first author is thankful to Dr Tariq Mairaj, Dr Hammad Raza, Dr Salman Atif, Dr Mohammad Salman, Junaid Aziz Khan of NUST and Dr Mohammd Ali Maud of UET Pakistan universities for their help and support. 


\section{References}

1. B. L. Markham, et al., The Landsat data continuity mission operational land imager (OLI) radiometric calibration. In IEEE Int. Geoscience and Remote Sensing Symp. (IGARSS), pp. 2283-2286 (2010).

2. U.S. Geological Survey, "Landsat Data Continuity Mission”, U.S. Geological Survey, Washington, DC (2012).

3. D. Gerace, Demonstrating Landsat's new potential to monitor coastal and inland Water. Ph.D dissertation, Dept. Imaging Science, Rochester Inst. Technol., Rochester, NY (2010).

4. A. Gerace, and J. Schott, The increased potential of the Landsat data continuity mission to contribute to case 2 water quality studies. In Proc. SPIE, Earth Observing Systems XIV, 7452, 74520U, San Diego, CA (Aug 2009).

5. N. Pehlevan, and J. R. Schott, Investigating the potential of the operational land imager (OLI) for monitoring case II waters using a look-up-table approach. In Pecora 18: Forty Years of Earth Observation-Understanding a changing World, Herndon, VA (2011).

6. S. N. Kloiber, P. L. Berezonik, L. G. Olmanson, and M. E. Bauer, A procedure for regional lake water clarity assessment using Landsat multispectral data. Remote Sens. Environ. 82, 38-47, (2002).

7. W. Pervez, Valiuddin, S. A. Khan, J. A. Khan, 2016. Satellite-based land use mapping: comparative analysis of Landsat-8, Advanced Land Imager, and big data Hyperion imagery. J. Appl. Remote Sens. 10 (2), 026004 (2016); doi: 10.1117/1.JRS.10.026004

8. D. Roy, M. Wulder, T. Loveland, C. Woodcock, R. Allen, , M. Anderson, D. Helder, J. Irons, D. Johnson, R. Kennedy, et al. Landsat-8: Science and product vision for terrestrial global change research. Remote Sens. Environ. 145, 154-172 (2014).

9. N. Flood, Continuity of Reflectance Data between Landsat-7 ETM+ and Landsat-8 OLI, for both top-of-atmospheric and surface reflectance. A Study in the Australian landscape, Remote Sens. 6, 7952-7970 (2014).

10. B. Markham, J. Barsi, G. Kvaran, L. Ong, E. Kaita, S. Biggar, J. Czapla-Myers, N. Mishra, D. Helder, Landsat-8 operational land imager radiometric calibrationand stability. Remote Sens. 6, 12275-12308 (2014).

11. J. Czapla-Myers, N. McCorkel, Anderson, K. Thome, S. Biggar, D. Helder, D. Aaron, L. Leigh, N. Mishra, The ground-based absolute radiometric calibration of Landsat 8 OLI. Remote Sens. 7, 600-626 (2015).

12. R. Morfitt, J. Barsi, R. Levy, B. Markham, E. Micijevic, L. Ong, P. Scaramuzza, K. Vanderwerff, Landsat-8 Operational land imager (OLI) radiometric performance on orbit. Remote Sens.7, 2208-2237 (2015).

13. E. Knight, G. Kvaran, Landsat-8 operational land imager design, characterization and performance. Remote Sens.6, 10286-10305, (2014).

14. P. Li, Jiag, Z. Feng, Cross-Comparison of Vegetation Indices Derived from Landsat-7 Enhanced Thematic Mapper (ETM_) and Landsat-8 Operational Land Imager (OLI) sensors. Remote Sens. 6, 310-329 (2014).

15. Y. Ke, J. Im, J. Lee, H. Gong, Y. Ryu, Characteristics of Landsat 8 OLI-derived NDVI by comparison with multiple satellite sensors and in-situ observations. Remote Sens. Environ.164, 298-313 (2015).

16. J. Rogan, D. Chen, Remote sensing technology for mapping and monitoring land cover and land use change. Progr. Plan. 61(4), 301-325 (2004). 
17. P. Sinha, L. Kumar, Indedpendent $t$ wo step thresholding of binary images in interannual land cover change/no cange identification. ISPRS J. Photogram. Remote Sensing 81, 31-43 (2013).

18. C. Benedek, M. Shadaydeh, Z. Kato, J. Sziranyi, Multilayer Markov Random Field models for change detection in optical remote sensing images. ISPRS J. Photogram. Remote Sensing (2015).

19. T. Blasche, Object based image analysis for remote sensing. ISPRS J. Photogram. Remote Sensing 65(1), 2-16 (2010).

20. J. Chen, M. Lu, X. Chen, J. Chen, L. Chen, A spectral gradient difference based approach for land cover change detection ISPRS J. Photogram. Remote Sensing 85, 1-12 (2013).

21. X. Chen, J. Chen, Y. Shi, Y. Yamaguchi, An automated approach for updating land cover maps based on integrated change detection and classification methods ISPRS J. Photogram. Remote Sensing 71, 86-95 (2012).

22. G. Metternicht, Change detection assessment using fuzzy sets and remotely sensed data: an application of topographic map revision. ISPRS J. Photogram. Remote Sensing 54(4), 221-233 (1999).

23. I. Bruzzone, D. F. Prieto, Automatic analysis of the difference image for unsupervised change detection . IEEE Trans. Geosci. Remote Sensing 38(3), 1171$1182(2000)$.

24. J. L. Silvan-Cardenas, I. Wang, On quantifying post- classification subpixel land cover changes. ISPRS J. Photogram. Remote Sensing 98, 94-105 (2014).

25. F. Bovolo, L. Bruzzone, M. Marconcini, A novel approach to unsupervised change detection based on a semisupervised SVM and a similarity measure. IEEE Trans. Geosci. Remote Sensing 45(7), 2070-2080 (2008).

26. C. He, A. Wei, P. Shi, Q. Zhang, Y. Zhao, Detecing land use/land cover change in rural-urban fringe areas using extended chabge-vector analysis. Int. J. Appl. Easth Observ. Geoinform. 13(4), (2011).

27. L. Bruzzzone, R. Cossu, G. Vernazza, Detection of land cover transitions by combining multidate classifiers, Pattern Recogn. Lett. 25(13) 1491-1500 (2004).

28. M.J. Canty, Image Analysis, and Change Detection in Remote Sensing: With Algorithms for ENVI/IDL, $2^{\text {nd }}$ ed.; CRC Press : Boca Raton, FL, USA, (2010).

29. A. Almutairi, T.A. Warner, Change Detection Accuracy and Image Properties: A Study Using Simuated Data. Remote Sens.2, 1508-1529, 2010.

30. A. Hecheltjen, F. Thonfeld, G. Menz, Recent advances in remote sensing change detection- A review. In Land Use and Land Cover Mapping in Europe, Manakos, I., Braun, M., Eds.; Springer Netherlands: Dordecht, The Neterlands, pp. 145-178, (2014).

31. D. Lu, P. Mausel, E. Brondizio, E.Moran, Change detection techniques. Int. J. Remote Sens. 25, 2365-2401 (2004).

32. P. Coppin, I. Jonckheere, K. Nackaerts, B. Muys, E. lambin, Review Article Digital Image change detection methods in ecosystem monitoring: A review. Int. J. Remote Sens. 25,1565-1596, (2004).

33. M. Hussain, D. Chen, A. Cheng, H. Wie, and Stanley, D., Change detection from Remotely Sensed Images: From Pixel-Based to Object -Based Approches. ISPRS J. Photogramm and remote Sensing 80: 91-106. Doi:10.1016/j.isprs.2013.03.006. (2013).

34. J. Unger, et al., Modelling of the Urban Heat Island Pattern Based on the Relationship between Surface and Air temperature. Quarterly Journal of the Hungarian Meterlogical Service 114, 287-302 (2010). 
35. L. Musci, L. Muladi, A. Henits, Farsang, and V. Albrecht, Large scale UHI Mapping Based on Spatial Information Provided by Young Volunteers. Carpathian Journal of Earth and Environmental Sciences 9 (2): 31-43 (2014).

36. D. Lu, E. Moran, and S. Hetrick, Detection of Impervious Surface Change with Multitemporal Landsat Images in an Urban-Rural Frontier. ISPRS J. Photogramm and remote Sensing, 66: 298-306. doi: 10.1016/j.isprsjprs.2010.10.010. (2011).

37. A. Schneider, Monitoring Land Cover Change in Urban and Peri-Urbanareas Using Dense Time Stacks pf Landsat Satellite Data a data Mining Approach. Remote Sens. Environ, 124,689-704. Doi:10.1016/j.rse.2012.06.006. (2012).

38. F. Yuan, K.E. Swaya, B. C. Loefffelholz, and M.E. Bauer, Land Cover Classification and Change Analysis of the Twin Cities (Minnesota) Metropolitan Area by Multitemporal Landsat Remote Sensing. Remote Sens. Environ, 98, (2-3) : 317-328. Doi:10.1016/j.rse.2005.08.006. (2005).

39. B.E. Hubbard, J.K. Crowley, Mineral mapping on the Chilean-Bolivian Altiplano using co-orbital ALI, ASTER and Hyperion imagery: data dimensionality issues and solutions, Remote Sens, 99, 173-186, 2005.

40. National Aeronautics and space administration, Earth Observing-1 Advanced Land Imager, 2002 http://eol.gsfc.nasa.gov/Technology/ALIhome1.htm

41. National Aeronautics and Space Administaration, Earth Observating-1 Eo1 General Mission, 2004 http://eol.gsfc.nasa.gov/new/general/

42. M.A. Wulder, J.C. White, S.N. Goward, G.M. Jeffrey, J.R. Irons, M.Herold, W.B. Cohen, T.R. Loveland, C.E. Woodcock, Landsat continuity: issues and opportunities for land cover monitoring. Remote Sens. Environ. 112, 955-969, (2008).

43. M. Folkman, J. Pearlman, L. Liao, and P. Jarecke, EO-1/ Hyperion hyperspectral imager design, development, characterization, and calibration in W. L. Smith and Y. Yasuoka, (Eds.). Hyperspectral Remote Sensing of the Land and Atmosphere 4151, 40-51, (2001).

44. L. C. Sanders, J. R. Schott, and R. Raqueno, A VNIR/SWIR atmospheric correction algorithm for hyperspectral imagery with adjacency effect. Remote Sens. Environ. 78, 252-263, (2001).

45. E. J. Hochberg, S. Andrefouet, and M. R. Tyler, Sea surface correction of high surface resolution Ikonos images to improve bottom mapping in near shore environment. IEEE Trans. Geosci. Remote Sens. 41, 1724-1729, (2003).

46. D. Mishra, S. Narumalani, D. Rundquist, and M. Lawson. Benthic habit mapping in tropical marine environments using Quick bird multispectral data. Photogramm. Eng. Remote Sens. 72, 1037-1048, (2006).

47. S. Andrefouet et al., Multi-site evaluation of IKONOS data for classification of tropical coral reef environments. Remote Sens. Environ. 88, 128-143, (2003).

48. M. Pal., Ensemble of support vector machines from land cover classification. Int. J. Remote Sens. 26(5), 1007-1011, (2008).

49. Y. Kavzoglu, and I. Colkesen., A kernel function analysis for support vector machines for land cover classification. Int. J. Appl. Earth Obs. Geoinf. 11, 352359, (2009).

50. A. Mathur, and G.M. Foody, Crop classification by support vector machine with intelligently selected training data for nonoperational application. Int. J. Remote Sens. 29(8), 2227-2240, (2008).

51. H. Hakvoort, et al., Towards airborne remote sensing of water quality in the Netherlands-Validation and error analysis. ISPRS J. Photogramm. Remote Sens. 57, 171-183, (2002). 
52. S. Thiemann, and H. Kaufmann. Lake water quality monitoring using hyperspectral airborne data-A semiempirical multispectral and multitemporal approach for the Mecklenburg Lake District, Germany. Remote Sens. Environ. 81, 228-237, (2002).

53. M. J. Canty, Boosting a fast neural network for supervised land cover classification. Comput. Geosci. 35(6), 1280-1295, (2009).

54. B. Dixon, and N. Candade, Multispectral land use classification using neural networks and support vector machines, one or the other, or both? Int. J. Remote Sens. 29(4), 1185-1206, (2008).

55. P. Barry, , EO-1/Hyperion Science Data User's Guide, Level 1_B. May 2001, http://www.eoc.csiro.au//hswww/oz_pi/doc/EO1HSDataUsersGuide.pdf (18 March 2016).

56. R.Beck, , EO-1 User Guide-Version 2.3, Satellite Systems Branch. USGS Earth Resources Observation Systems Data Center, Cincinnati, (2003).

57. B. W. Pengra, C. A. Johnston, and T. R. Loveland, Mapping an invasive plant, Phragmites australis, in coastal wetlands using the EO-1 Hyperion hyperspectral sensor. Remote Sens. Environ. 108(1), 74-81 (2007).

58. D. D. Xu, G.-Q. Ni, L.-L. Jiang, Y.-T.Shen, T.-L. S. Li, Ge, and X.-B. Shu, Exploring for natural gas using reflectance spectra of surface soils. Adv. Space Res. 41, 1800-1817 (2008).

59. R. Zhang, and J. Ma, Feature selection for hyperspectral data based on recursive support vector machines. Int. J. Remote Sens. 30(14), 3669-3677 (2009).

60. P. Du, K. Tan, and X. Xing, Wavelet SVM in reproducing kernel Hilbert space for hyperspectral remote sensing image classification. Opt. Commun. 283, 4978-4984 (2010).

61. S. Pignatti, R. M. Cavalli, V. Cuomo, V. Fusilli, S. Pascucci, M. Poscolieri, et al., Evaluating Hyperion capability for land cover mapping in a fragmented ecosystem: Pollino National Park, Italy. Remote Sens. Environ. 113, 622-634, (2009).

62. J. Wang, Y. Chen, T. He, C. Lv, A. Liu, Application of geographic image cognition approach in land type classification using Hyperion image: A case study in China, Int. J. Appl. Earth Obs. Geoinf. 12S, S212-S222, (2010).

63. S. J Walsh, A. L. McCleary, C. F. Mena, Y. Shao, J. P. Tuttle, A. González, et., Quick Bird and Hyperion data analysis of an invasive plant species in the Galapagos Islands of Ecuador: Implications for control and land use management. Remote Sens. Environ. 112, 1927-1941, (2008).

64. C. Huang, L. S. Davis, and G. Jr. Townshend, An assessment of support vector machines for land cover classification. Int. J. Remote Sens. 23, 725-749, (2002).

65. H. Nemmour, and Y. Chibani, Multiple support vector machines for land cover change detection: An application for mapping urban extension. ISPRS J. Photogramm. 61, 125-133, (2006).

66. M. L. Clark, D. A.Roberts, and D. B. Clark, Hyperspectral discrimination of tropical rain forest tree species at leaf to crown scales. Remote Sens. Environ. 96, 375-398, (2005).

67. D. Vyas, N. S. R. Krishnayya, K. R. Manjunat, S. S. Ray, and S. Painigraphy, Evaluation of classifiers for processing Hyperion (E-O1) data of tropical vegetation. Int. J. Appl. Earth Obs. Geoinf. 13 228-235, (2011).

68. D.G. Googenough et al., Processing Hyperion and ALI for forest classification. IEEE Trans. Geosci. Remote Sens 41, 1321-1331, (2003).

69. M. Dalponte, L. Bruzzone, L. Vescovo, and D. Gianelle, The role of spectral resolution and classifier complexity in the hyperspectral images of forest areas. Remote Sens. Environ. 113, 2345-2355, (2009). 
70. A. Plaza, et al., Recent advances in techniques for hyperspectral image processing. Remote Sens. Environ. 113, S110-S122, (2009).

71. F. Melgani, and L. Bruzzone, Classification of hyperspectral remote sensing image with support vector machines. IEEE T. Geosci. Remote 42, 1778-1790, (2004).

72. M. Pal, and P. M. Mather, Some issues in the classification of DAIS hyperspectral data. Int. J. Remote Sens. 27, 2895-2916, (2006).

73. S. G. Ungar, J. S. Pearlman, J. A. Mendenhall, Reuter, D., Overview of the earth observing one (E-O1) mission. IEEE Trans. Geosci. Remote. 41, 1149-1159, (2003).

74. D. Roy, M. Wulder, T. Loveland, R. Allen, M. Anderson, D. Helder, J. Irons, D. Johnson, R. Kennedy, T. Scambos, Landsat-8: Science and product vision for terrestrial global change research. Remote Sens. Environ. 145, 154-172, (2014).

75. D. R. Hearn, C. J. Digenis, D. E. Lencioni, Mendenhall, J. A., Evans, J. B., Walesh, R. D., E-O1 advanced land imager overview and spatial performance. IEEE Trans. Geosci. Remote Sens. 2, 897-899, (2001).

76. Landsat 8 (L8) Data Users Handbook (2015), LSDA-1574 Version 1.0, Department of the Interior U.S. Geological Survey, EROS Sioux Falls, South Dokota.

77. P. S. Thenkabail, E. A. Enclona, M. S. Ashton, and B. Van Der Meer, Accuracy assessments of hyperspectral waveband performance for vegetation analysis applications. Remote Sens. Environ. 91(3-4), 354-376, (2004a).

78. P. S. Thenkabail, E. A. Enclona, M. S. Ashton, C. Legg, and M. J. D. Dieu, Hyperion, IKONOS, ALI and ETM+ sensors in the study of African rainforests. Remote Sens. Environ. 90, 23-43, (2004b).

79. B. Datt, et al., Preprocessing EO-1 Hyperion hyperspectral data support the application of agriculture indexes. IEEE Trans. Geosci. Remote Sens. 41, 1246$1259,(2003)$.

80. M. G. Allan, D. Hamiton, B. J. PHicks, and L. Brabyn, Landsat remote sensing of chlorophyll a concentration in central North Island lakes of New Zealand. Int. J. Remote. Sens., 32, 2037-2055, (2011).

81. Y. H. Ahn, P. Shanmugam, and J. E. Moon, Retrieval of ocean colour from high resolution multi-spectral imagery for monitoring highly dynamic ocean features. Int. J. Remote. Sens., 27, 367-392, (2006).

82. B. L. Markham, M. O. Haque, J. A. Barsi, E. Micijevic, D. L. Helder, K. J. Thome, D. Aaron, and J. S. Czapla-Myers, Landsat-7 ETM+: 12 years on-orbit reflectiveband radiometric performance. IEEE Trans. Geosci. Remote Sens. 50(5), 20562062, (2012).

83. D. A. Palandro, et al., Qualification of two decades of shallow-water coral reef habitat decline in the Florida Keys National Marine Sanctuary using Landsat data (1984-2002). Remote Sens. Environ. 112, 3388-3399, (2008).

84. V. E. Brando, and A. G. Dekker, Satellite hyperspectral remote sensing for estimating estuarine and coastal water quality. IEEE Trans. Geosci. Remote Sens. 41, 1378-1387, (2003).

85. C. D. Mobley, and L. K. Sundman, Hydrolight 5, Ecolight User Guide, Bellevue, WA: Sequoia Scientific, Inc., (2008).

86. Z. Lee, Y. H. Ahn, C. Mobley, and R. Arnone, Removal of surface reflected light for the measurement of remote-sensing reflectance from an above-surface platform. Opt. Express, 18, 26313-26324, (2010).

87. K. G. Ruddick, F. Ovidio, and M. Rijkeboer, Atmospheric correction of SeaWiFS imagery for turbid coastal and inland waters. Appl. Opt. 39, 897-912, (2000). 